\title{
IMPACTS OF CLIMATE CHANGE ON NET PRIMARY PRODUCTION: A MODELLING STUDY AT PAN-EUROPEAN SCALE
}

\author{
SAKALLI, A. \\ Faculty of Marine Sciences and Technology, Iskenderun Technical University \\ P.O. Box 31200 Iskenderun, Hatay, Turkey \\ e-mail: as@abdulla-sakalli.com; phone: +903266141693; fax: +903266141877 \\ (Received $14^{\text {th }}$ Jul 2016; accepted $29^{\text {th }}$ Oct 2016)
}

\begin{abstract}
Identification of the net primary production capacity of European vegetated areas has been becoming the meaning since last decades. Responses of carbon uptake by autotrophs and storage in terrestrial ecosystems under environmental changes is quite important to understand and predict the biogeochemical cycles, and thus the interactions between atmosphere and terrestrial biosphere in the future. Remote sensing of the Earth systems has been having very important roles for calibration of the modelling results during last 20 years. In this paper, we simulate the impacts of the climate change and elevated $\mathrm{CO}_{2}$ in the atmosphere on net primary production by autotrophs by using Community Land Model vers. 4.5 (CLM4.5) with remarkable high grid resolution (i.e. $25 \times 25 \mathrm{~km}$ ) at pan-European scale. We especially focused on the time period in the future when the global warming reaches the $2^{\circ} \mathrm{C}$ (i.e. 2034-2063) in Europe. The CLM4.5 model performs quite good in Western and Southern Europe. Although the model predicts the NPP ca. 2 times higher than the remote sensed NPP by MODIS, the analysis between in-situ data and CLM4.5 shows better correlation than between in-situ data and remote sensed NPP in 19 study areas. Despite of the higher correlation of the model with in-situ data, it is still needed long-term observation studies needed from different biome types and plant functional types.
\end{abstract}

Keywords: biogeochemical cycle, COP21, CLM4.5, MODIS, remote sensing

\section{Introduction}

Net Primary Production (NPP) is one of the most important keywords for investigation of the climate change effect on carbon uptake and storage by photosynthetic organisms. Numerous studies focused on determining the climate change impacts on NPP in the terrestrial ecosystems (Melillo et al., 1993; Cao and Woodward, 1998; Bonan, 2008; Ummenhofer et al., 2015). Plant productivity is a very important aspect in the global biogeochemical cycles especially in global carbon cycle due to the absorption of a part of anthropogenic emitted $\mathrm{CO}_{2}$ from the atmosphere (Esser et al., 2012). NPP is also a quite essential parameter for all ecosystems, since it can illustrate the quality and quantity of absorbing the incoming solar energy, and also indicates the fundamental energy source for all heterotroph organisms in the ecosystems. The potential change in the primary production in the terrestrial and marine ecosystems under global $2{ }^{\circ} \mathrm{C}$ average temperature increase has been discussing since the last decades (Chust et al., 2014; Guanter et al., 2014; Danelichen et al., 2015). Among others, Kirschbaum (2000) studied the responses of vegetation growth, photosynthesis, and respiration to the change climate from pre-industrial time (i.e. 1900) up to 2100. In his study, it has been mentioned that a $2{ }^{\circ} \mathrm{C}$ increase in global average temperature affects the physiological and biological processes of various plant species that especially distribute in a narrow temperature niches. On the other hand, a $20 \%$ of yield increase in crop plants was reported under global average temperature increase up to 2 ${ }^{\circ} \mathrm{C}$ within the fourth assessment report of the Intergovernmental Panel on Climate 
Change (IPCC) (Easterling et al., 2007). In the assessment report, it was also pointed to a decline in crop yield with increasing temperature after $2{ }^{\circ} \mathrm{C}$ increasing period. Wan et al. (2005) quantified a similar impact of temperature increase in semi-natural vegetation (i.e. grassland). In their field study, they monitored about $19 \%$ increase in above ground net primary production under $2{ }^{\circ} \mathrm{C}$ temperature warming. Certainly, not only the temperature but also precipitation, solar energy, humidity and wind speed have significant impacts on the NPP (Wan et al., 2005). In a Chihuahuan desert grassland, Thomey et al. (2011) studied the effect of precipitation on net primary production. They quantified a substantive increase in NPP due to an increase in precipitation in the study areas. Approximately $1.3 \%$ of incoming solar energy is absorbed by plants during the growing season. A substantial accumulation of net biomass takes in some vegetated regions from decades to centuries, which indicates that such vegetated regions actually points to net sink of carbon (Dixon et al., 1994). For instance, temperate and boreal forests are the main green areas for sink of carbon in pan-European region. Kauppi et al. (1992) referenced to a $\sim 0.12 \mathrm{Pg} \mathrm{C}$ estimated annual carbon fluxes in that forests.

Estimation and measurement of NPP are carried out by various methods in the terrestrial ecosystem (Lieth, 1975; Esser, 1998; Zhao et al., 2005). For such aims, enhanced remote sensing of NPP has been widely using to study, quantify, and understand the carbon uptake and storage capacity of the terrestrial ecosystems since last decades (Liu et al., 1997; Turner et al., 2004; Maselli et al., 2013; Pachavo and Murwira, 2014; Wang, 2016). Although remote sensing performs good results for NPP at global or regional scale, the satellite or radars have some technical difficulties in estimating of NPP under cloudy or snowy days. That leads often to under- or overestimation of NPP in the terrestrial biosphere (Zhao et al., 2005, 2006, 2010; Pan et al., 2006; Turner et al., 2006). Compared to the remote sensing methods, earth system models can deliver often quite good results for NPP in terrestrial biosphere (PrietoBlanco et al., 2009; Donmez et al., 2011).

In this paper, we aimed to define the carbon storage capacity in high grid resolution at pan-European scale, and investigate the behaviour of carbon sink areas under climate change. Those produce new aspects to estimate of net carbon storage in European terrestrial biosphere. This is an important issue to find out how will the carbon storage capacity of terrestrial ecosystem be affected by changing the combination of the relevant climate parameter in the $2{ }^{\circ} \mathrm{C}$ global warming period in the future. It also gives data about the carbon storage capacity of European vegetation in the future when the global average temperature increases up to $2{ }^{\circ} \mathrm{C}$.

Also the main objectives of the study were: $(i)$ to describe the spatio-temporal heterogeneity in NPP by using remote sensed and modelled data, (ii) to quantify the difference between the remote sensed and modelled NPP, (iii) to identify the relationship between the climate conditions and modelled NPP, (iv) to indicate the change in NPP during the $2{ }^{\circ} \mathrm{C}$ global average temperature increase period.

\section{Material and Methods}

\section{Model Initialization}

For estimating of net primary production, the Community Land Model version 4.5 (CLM4.5) was established on $25 \times 25 \mathrm{~km}$ grid resolution at pan-European scale. The model was run with bias corrected climate data for 800 years in ad-hoc (accelerated method) mode to get the main carbon pools of the terrestrial biosphere (e.g. soil 
carbon, vegetation carbon, total ecosystem carbon etc.) in steady state. The accelerated method of the model, which based on the acceleration of decomposition rates for a spin-up phase in CLM4.5, describes the steady state process of the model. By this method, the main aim is an approximation of steady state conditions for the CLM4.5 model by using specific characteristics of the model dynamics for producing individual time processes via the model condition space, and methods of multivariate minimization that repeatedly investigate multiple time processes by condition space in searching of reasonable equilibrium solutions. The detailed description of the algorithms for the ad-hoc method and steady state runs (spin-up) was published by Thornton and Rosenbloom (2005).

We first run the model with the ad-hoc method for 800 years to get the carbon pools in the ecosystems in equilibrium. Within this run, we used stable climate conditions that were taken from the ensemble average of 30-year historical run of the used regional climate model in monthly resolution. After reaching the carbon pools of the ecosystems (i.e. carbon pools in soil and vegetation) the steady state we switched of the ad-hoc method and run the model with the normal decomposition rates but the same climate data up to 1950 . Thereafter, we forced the model with bias corrected monthly climate data from 1950 to 2100. For the future period (i.e. from 2004 to 2100), the bias corrected climate data were simulated by used regional climate model under consideration the Representative Concentration Pathway 4.5 (RCP4.5) (see Sec. 2.2).

\section{Atmospheric Forcing Data}

In this study, we used six climate parameters (see Tab. 1) from outputs of the Rossby Centre Regional Atmospheric Model (SMHI-RCA4), which was driven by EC-EARTH General Circulation Model (GCM), to force the CLM4.5 for the study periods. The RCM model was used to downscale transient global climate projections, i.e. ECEARTH's outputs as boundary conditions, over Europe at a $25 \mathrm{~km}$ spatial resolution (Jacob et al., 2014; Strandberg et al., 2014). For this aim, the RCM considered the Representative Concentration Pathway 4.5 (RCP4.5) for prediction the climate parameter from 2004 to 2100.

Table 1. The used climate variable for atmospheric forcing of CLM4.5 model

\begin{tabular}{|l|l|}
\hline Code & Variable name as daily mean value (unit) \\
\hline tas & Surface temperature at $2 \mathrm{~m}\left({ }^{\circ} \mathrm{C}\right)$ \\
\hline $\mathrm{pr}$ & Sum of precipitation $(\mathrm{mm})$ \\
\hline rlds & Surface downwelling longwave radiation $\left(\frac{\mathrm{W}}{\mathrm{m}^{2}}\right)$ \\
\hline rsds & Surface downwelling shortwave radiation $\left(\frac{\mathrm{W}}{\mathrm{m} 2}\right)$ \\
\hline huss & Near surface specific humidity $\left(\frac{\mathrm{kg}}{\mathrm{kg}}\right)$ \\
\hline sfcWind & Near surface wind speed $\left(\frac{\mathrm{m}}{\mathrm{sm}}\right)$ \\
\hline
\end{tabular}




\section{Model Description}

After spinning up of the model, we run it with required climate data from 1970 to 2100. According to the simulations which show the start of $2^{\circ} \mathrm{C}$ global average temperature increase in ca. 2030 and the end in ca. 2060, we take two 30 year periods (1970-2000 and 2030-2060) for investigation the change of the NPP in past observed period (1970-2000) and future projected period (2030-2060). The version of the model uses the 17 plant functional types (PFTs) from the study of Lawrence \& Chase (2007).

The NPP is formulated in the CLM4.5 as

$$
N P P=G P P-\left(M_{R}+G_{R}\right)
$$

where $M_{R}$ is for maintenance and $G_{R}$ is for growth respiration. Maintenance growth respiration is mainly calculated by sum of carbon fluxes in leaf, fine root, live steam and live root (see Eq. 1).

$$
M_{R}=C F_{\text {leaf }}+C F_{\text {froot }}+C F_{\text {livestem }}+C F_{\text {livecroot }}
$$

where $C F_{\text {leaf }}, C F_{\text {froot }}, C F_{\text {livestem, }}$, and $C F_{\text {livecroot }}$ is maintenance respiration costs for leaf, fine root, live stem, and live coarse root, respectively.

Growth respiration is also calculated as $30 \%$ of the total carbon in new growth (Larcher, 1995 "Physiological Plant Ecology").

$$
G_{R}=0.3 \times G P P
$$

In its simplest form, GPP is modelled in CLM4.5 by considering the carboxylation as:

$$
G P P=\min \left(A_{c}, A_{j}, A_{p}\right)
$$

The RuBP carboxylase (Rubisco) limited rate of carboxylation Ac $\left(\mu \mathrm{mol} \mathrm{CO} 2 \cdot \mathrm{m}^{-2} \cdot \mathrm{s}^{-1}\right)$ is

$$
A_{c}=\left\{\begin{array}{ll}
\frac{V_{c \max }\left(c_{i}-\Gamma_{0}\right)}{c_{i}+K_{e}\left(1+\frac{0_{i}}{K_{0}}\right)} & \text { for } C_{3} \text { plants } \\
V_{c \max } & \text { for } C_{4} \text { plants }
\end{array}\right\} \quad c_{i}-\Gamma_{*} \geq 0 .
$$

The light limited maximum rate of carboxylation that allows to regenerate $\mathrm{RuBP} \mathrm{Aj}$ $\left(\mu \mathrm{mol} \mathrm{CO} 2 \cdot \mathrm{m}^{-2} \cdot \mathrm{s}^{-1}\right)$ is

$$
A_{j}=\left\{\begin{array}{ll}
\frac{V_{c \max }\left(c_{i}-\Gamma_{\vartheta}\right)}{4 c_{i}+8 \Gamma} & \text { for } C_{3} \text { plants } \\
\alpha(4.6 \phi) & \text { for } C_{4} \text { plants }
\end{array}\right\} \quad c_{i}-\Gamma_{*} \geq 0 .
$$

The product-limited and PEP carboxylase-limited rate of carboxylation for C3 and $\mathrm{C} 4$ plants $\mathrm{Ap}\left(\mu \mathrm{mol} \mathrm{CO} 2 \cdot \mathrm{m}^{-2} \cdot \mathrm{s}^{-1}\right)$ is 


$$
A_{p}=\left\{\begin{array}{ll}
3 T_{p} & \text { for } C_{3} \text { plants } \\
k_{p} \frac{c_{i}}{P_{\text {atm }}} & \text { for } C_{4} \text { plants }
\end{array}\right\}
$$

In the equations of the carboxylation, $c_{i}$ is the partial pressure of $\mathrm{CO}_{2}$ in internal leaf $(\mathrm{Pa}), O_{i}$ is the partial of $\mathrm{O}_{2}(\mathrm{~Pa}), K_{c}$ and $K_{o}$ are the Michaelis-Menten constants $(\mathrm{Pa})$ for $\mathrm{CO}_{2}$ and $\mathrm{O}_{2} . \Gamma_{*}$ is the $\mathrm{CO}_{2}$ compensation point. $V_{c \max }$ is the maximum rate of $C$ assimilation $\left(\mu \mathrm{mol} \cdot \mathrm{m}^{-2} \cdot \mathrm{s}^{-1}\right)$. J stands for electron transport rate $\left(\mu \mathrm{mol} \cdot \mathrm{m}^{-2} \cdot \mathrm{s}^{-1}\right), T_{p}$ for triose phosphate utilization rate $\left(\mu \mathrm{mol} \cdot \mathrm{m}^{-2} \cdot \mathrm{s}^{-1}\right) \cdot \phi$ is the absorbed photosynthetically active radiation $\left(\mathrm{W} \cdot \mathrm{m}^{-2}\right)$ and $k_{p}$ is the initial slope of $\mathrm{C}_{4} \mathrm{CO}_{2}$ response curve. The detailed description of the parameters can be found in the study by Oleson et al. (2013).

\section{Model Simulations Design}

The simulation of the NPP was continuously done by the model from 1950 to 2100 . We analyzed two 30-year time periods, i.e. 1971-2000 and 2031-2060 as historical and future period, respectively. The selected 30-year time periods were chosen according to the IPCC AR5 report (Kirtman et al., 2013), i.e. 1971-2000 as a base line for depicting near term climate change affects, and the period in that the global average temperature reached the $2{ }^{\circ} \mathrm{C}$ in the RCP4.5 scenario, i.e. 2031-2060 as a base line for depicting future climate change impacts on the NPP at pan-European scale.

\section{Observation Data}

The comparison and correlation analysis of the model results were done by using in-situ measurement data from six different data sources. We selected the locations with the NPP data from the data sources by considering the same biome and plant functional types (PFT) similar as in grid cells of the CLM4.5 model. We also considered the time periods of the insitu measurements for comparison of the simulated and measured NPP in a grid cell.

\section{Intercomparison of the Model}

For intercomparison of the modelled NPP, we used the available monthly NPP data from MODIS (Moderate Resolution Imaging Spectro-radiometer) satellite for the time range between 2000 and 2014. The data were released within MOD17 project and provided continuous estimates of NPP in ca. $4 \mathrm{~km}$ resolution across the Earth's vegetated land surface (Zhao and Running, 2010). We used bilinear interpolation method of Climate Data Operators (CDO) to upscale MODIS results from $4 \times 4 \mathrm{~km}$ to model output grid resolution (i.e. $25 \times 25 \mathrm{~km}$ ) for this study (CDO, 2015). The detailed description of the bilinear interpolation method and module is published by Schulzweida (2015). The correlation analysis between the in-situ data, and predicted and remote sensed data were carried out with IBM SPSS statistic software version 23.

\section{Result and Discussion}

Net primary production (NPP) was obtained from the MODIS sensor at $4 \mathrm{~km}$ spatial resolution for the pan-European terrestrial surface. In Fig. 1-left, the original 4x4 km resolution NPP and Fig. 1-right the from $4 \times 4 \mathrm{~km}$ to $25 \times 25 \mathrm{~km}$ up-scaled NPP are shown. It is to see that the upscale method does not change the quality and distribution 
of the NPP data in domain of the study. As it is expected, the highest 15-year average NPP value ( $2200 \frac{g C}{m^{2} y r}$ from 2000 to 2014) was taken by MODIS in temperate broadleafed and mixed forests in pan-European region (see Fig. 1). In temperate biomes, the dominant plant species are generally Fagus spp., Quercus spp., Betula spp. and Carpinus spp. (Schmithüsen, 1976; Olson et al., 2001). NPP was quantified between 300 and $600 \frac{g C}{m^{2} y r}$ by the satellite in boreal forests of northern and eastern

Europe (see Fig. 1). A long the Mediterranean cost, where vegetated areas are dominated by sclerophyllous shrub formation and evergreen seasonal dry forests with Q. ilex ranges the NPP between 200 and $1050 \frac{g C}{m^{2} y r}$ (see Fig. 1).

In the Table 2, we summarize NPP values from seven different published sources from different times for three main biome types of pan-European vegetated regions. In that biome regions, the NPP values between 153 and $550 \frac{g C}{m^{2} y r}$. Lieth (1975) was published quite similar NPP value for regions with temperate broadleafed and mixed, and boreal forests (see Tab. 2 col. 1). The value of NPP ranged from 600 to $2500 \frac{g C}{m^{2} y r}$ for temperate and 200 to $1500 \frac{g C}{m^{2} y x}$ in boreal biomes. Esser (2008) and Chapin et al. (2011) published similar NPP data to the estimation of NPP by MODIS in temperate and boreal regions (see Table $2 \mathrm{col} .2$ and 5). Compared to considered data in the table, Del Grosso et al. (2008) and Huston and Wolverton (2009) addressed the minimum range for NPP in all three biome types (see Table 2 col. 3 and 4).
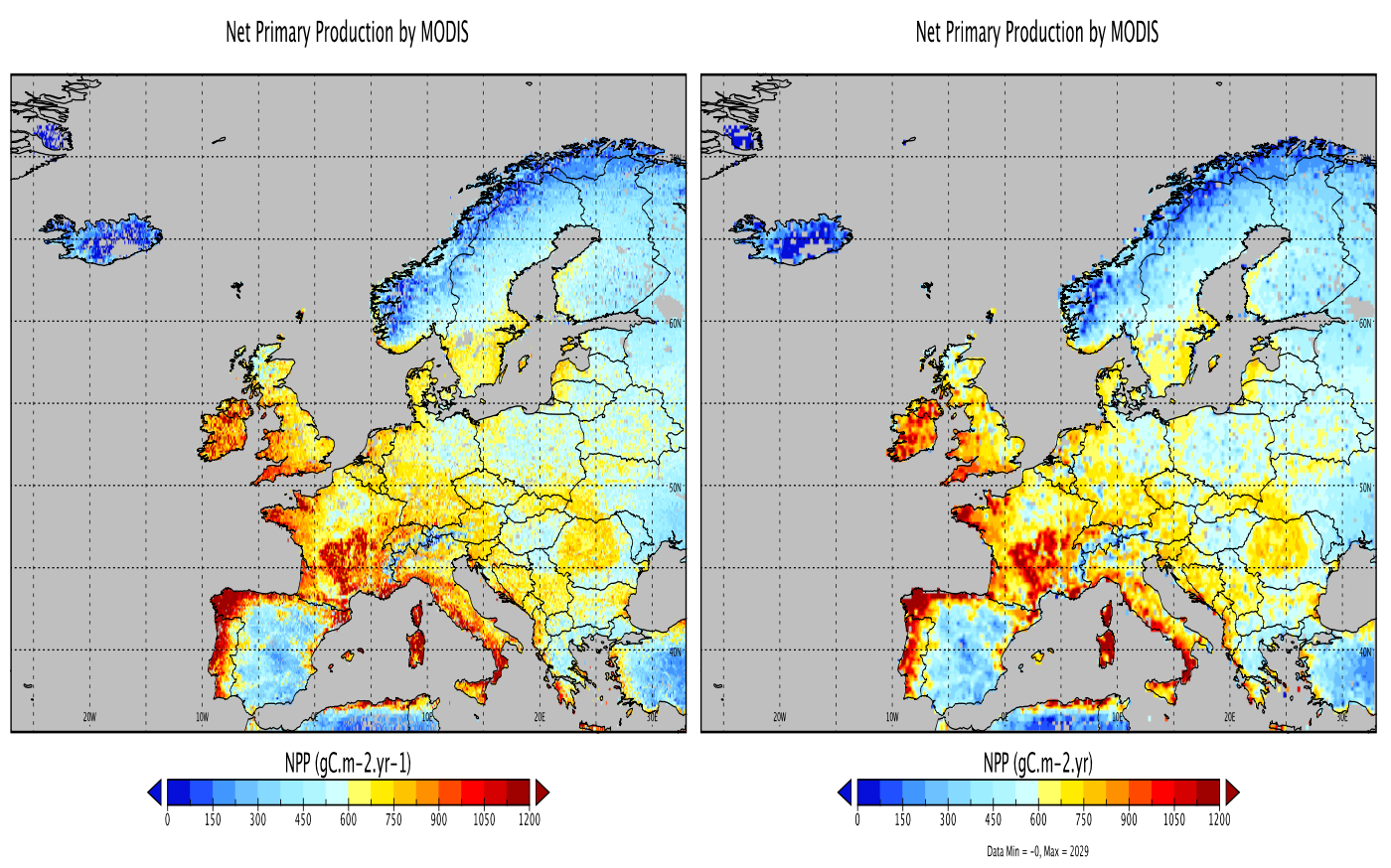

Figure 1. The spatial distribution of NPP averaged over the period of 2000-2014. The left subfigure represents NPP in $4 \times 4 \mathrm{~km}$ resolution and the right shows the up-scaled NPP to $25 \times 25 \mathrm{~km}$ spatial resolution 
Table 2. Net Primary Production (in $\mathrm{gC} \cdot \mathrm{m}^{-2} \cdot \mathrm{yr}^{-1}$ ) from different sources for the three main climate zones in pan-European region. The climate zones include broadleafed and needleleaf with deciduous and evergreen plant functional types. The sources were chronological order.

\begin{tabular}{|l|l|l|l|l|l|l|l|}
\hline & 1 & 2 & 3 & 4 & 5 & 6 & 7 \\
\hline Temperate & $600-2500$ & $960-1280$ & $400-800$ & $625-779$ & 1550 & $615-2200$ & $550-1890$ \\
\hline Boreal & $200-1500$ & $161-348$ & $100-600$ & $190-234$ & 375 & $155-550$ & $320-630$ \\
\hline Mediterrenean & $200-1000$ & ----- & $50-600$ & ----- & 1000 & $310-1030$ & $355-980$ \\
\hline Grassland & $100-1500$ & $58-1623$ & $50-800$ & $298-641$ & $750-1080$ & $150-1050$ & $260-940$ \\
\hline
\end{tabular}

1. Lieth, H., 1975

2. Esser, G., 1998

3. Del Grosso et al., 2008

4. Huston and Wolverton, 2009

5. Chapin et al., 2011

6. MODIS, 2000-2014 this study

7. CLM4.5, 2000-2014 this study

In general, CLM4.5 model predicts the NPP quite similar to the MODIS estimations in all 3 biome types in pan-European domain (see Table 2 col. 6). We compare the distribution of 15 years' average NPP in pan-European domain. In Figs. 2 and 3, we illustrate the distribution of NPP by MODIS and CLM4.5 in pan-European domain.

Although the NPP by CLM4.5 and MODIS have similar pattern, there is particularly some differences in temperate broadleafed and mixed forests. In Eastern Europe the CLM4.5 predicts the NPP in most of the regions over $1000 \frac{g c}{m^{2} y r}$, however the MODIS supplies the NPP between 300 and $700 \frac{g C}{m^{2} y r}$. We plotted spatial distribution of 15 years (2000-2014) average of all six climate variables in the Fig. 4.
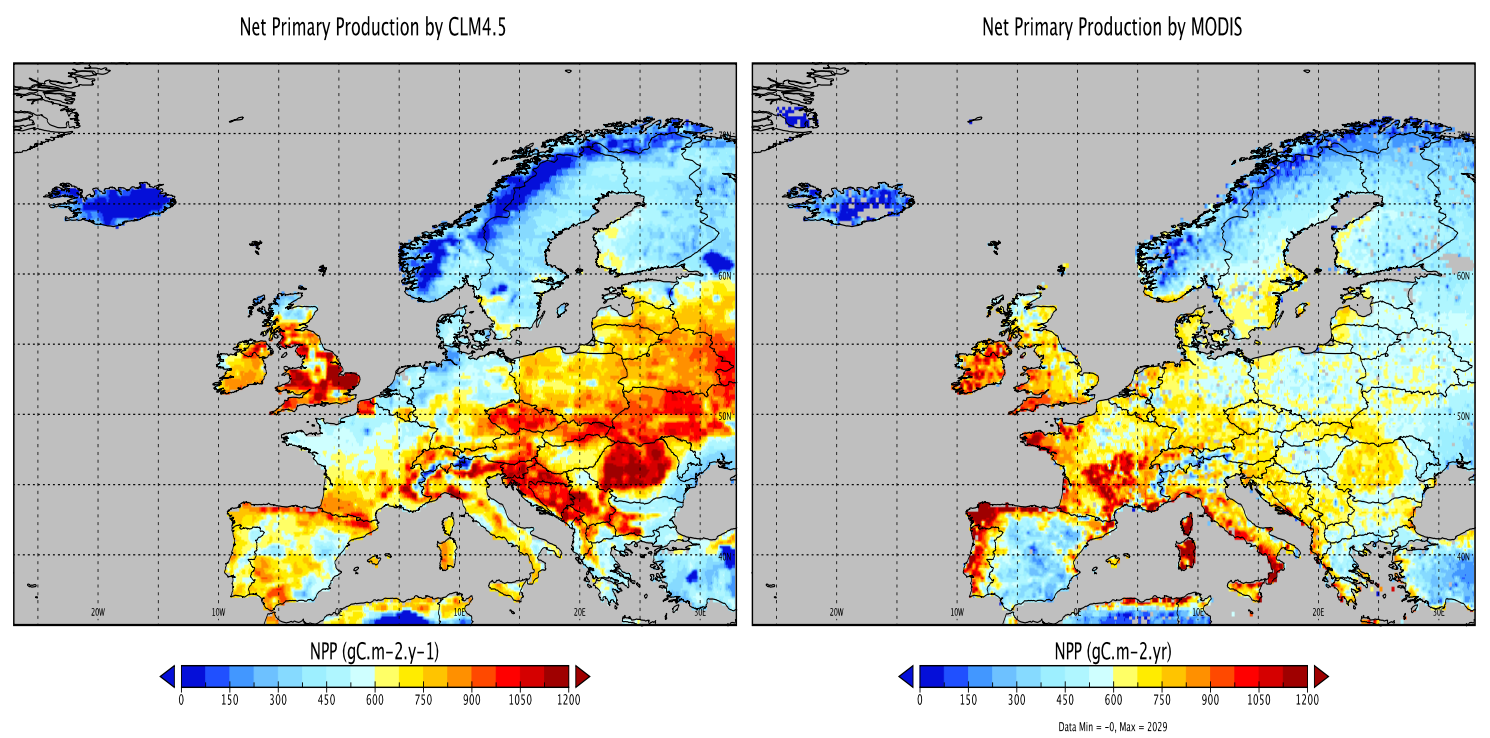

Figure 2. Spatial distribution of 15 years (2000-2014) average predicted by CLM4.5 and observed by MODIS at pan-European level 


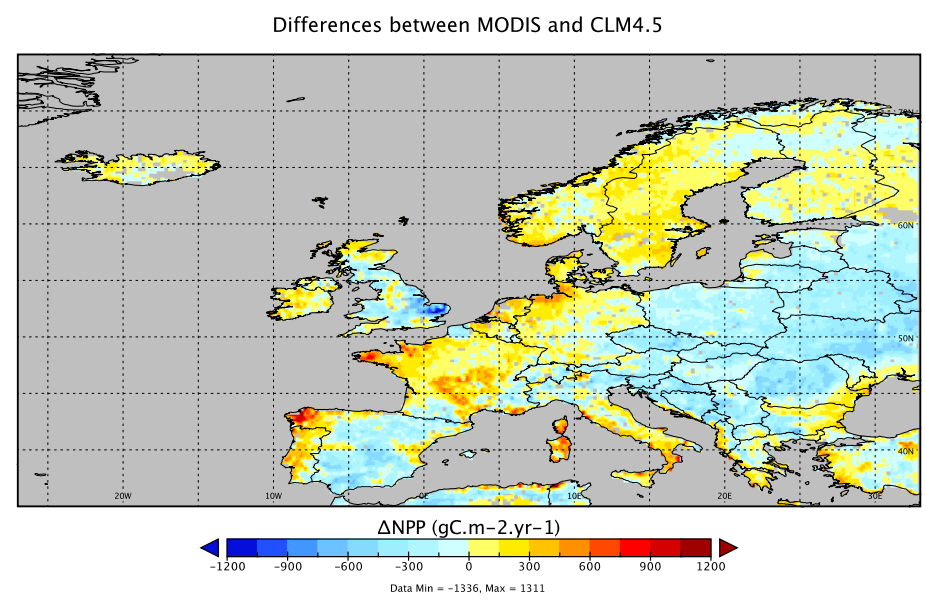

Figure 3. Spatial distribution of the difference between 15 years average of by MODIS observed and by CLM4.5 predicted NPP at pan-European scale
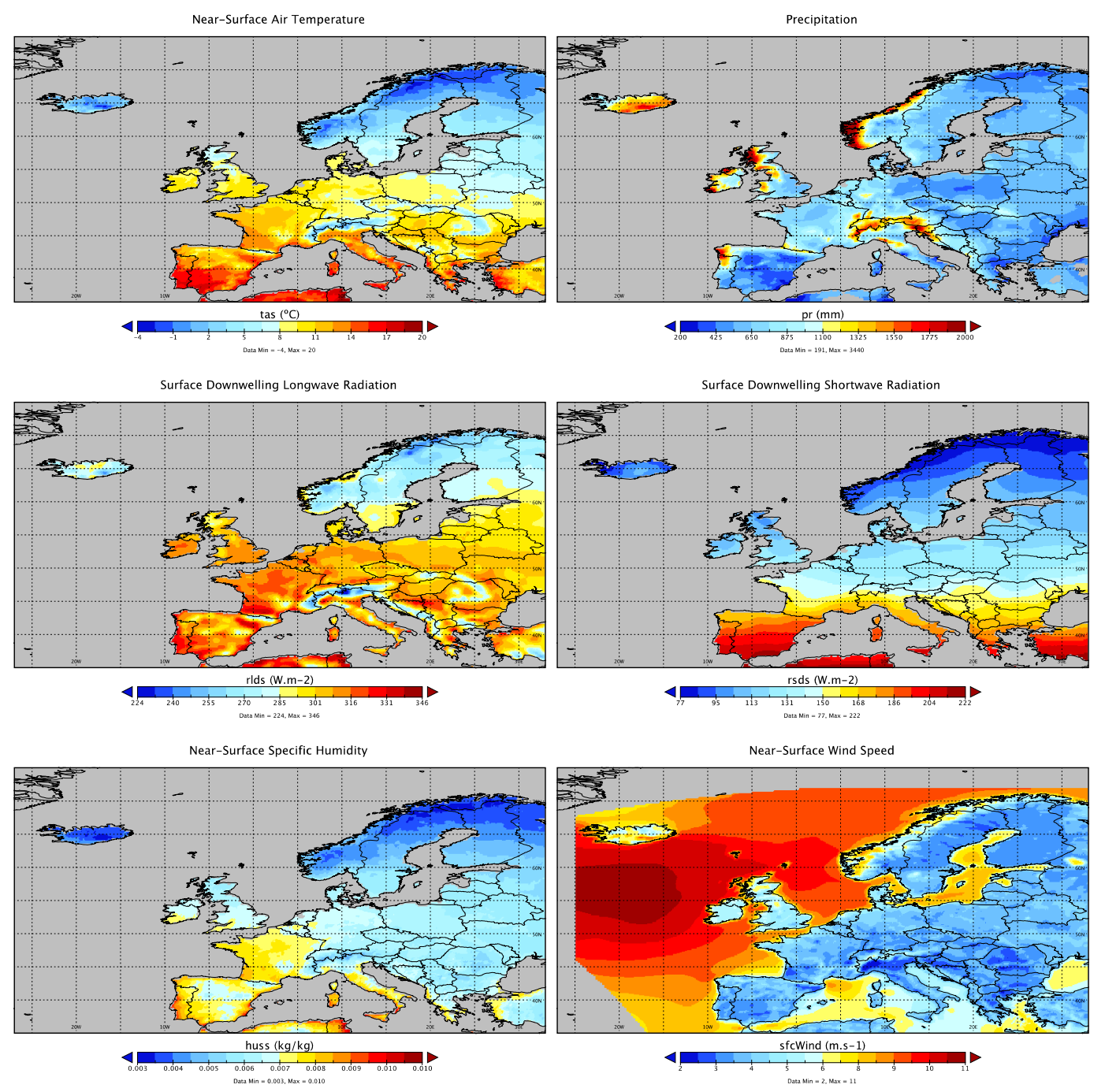

Figure 4. Distribution of 15 years (2000-2014) average of six climate variables at panEuropean scale 
The multi regression analysis shows no correlation between the NPP and used six climate parameter at the time range 2000-2014 (see Tab. 3). But, by visual comparison the climate plots in the regions with high differences in NPP between the model and obtained satellite data, it's to see that the differences are mainly due to combination effect of temperature and precipitation in eastern Europe (see Fig. 2).

Table 3. Multi regression correlation between predicted NPP and six climate variable at the time range 2000-2014

\begin{tabular}{|c|c|c|c|c|c|c|}
\hline & NPP & huss & $\mathrm{pr}$ & rlds & rsds & sfcWind \\
\hline huss & .270 & & & & & \\
\hline $\mathrm{pr}$ & -.044 & -.125 & & & & \\
\hline rlds & .374 & $.870^{\star \star}$ & -.360 & & & \\
\hline rsds & .204 & $.653^{* \star}$ & $-.562^{*}$ & $.863^{\star \star}$ & & \\
\hline sfcWind & -.105 & $-.643^{\star \star}$ & .421 & $-.740^{\star \star}$ & $-.907^{\star \star}$ & \\
\hline tas & .329 & $.806^{\star \star}$ & $-.539^{\star}$ & $.904^{\star *}$ & $.904^{\star *}$ & $-.733^{\star *}$ \\
\hline \multicolumn{7}{|c|}{$\begin{array}{l}{ }^{* *} \text {. Correlation is significant at the } 0.01 \text { level (2-tailed). } \\
{ }^{*} \text {. Correlation is significant at the } 0.05 \text { level ( } 2 \text {-tailed). } \\
\mathrm{N}: 15\end{array}$} \\
\hline
\end{tabular}

That confirms that the NPP distinctions between the predicted and observed in the 4 regions are mainly depending on climate parameter and not on the parametrization of NPP for PFTs in the model. It is quite important to mention that the differences between the modelled and observed NPP does generally not mean that the quality of NPP modelling has substandard quality. Zhao et al. (2006) published data about uncertainties in quantifying the GPP (Gross Primary Production) and NPP by MODIS. They highlighted that the quantifying of NPP includes more uncertainties then GPP by MODIS. To clarify the origin of differences between CLM4.5 and MODIS, we validated the NPP products (CLM4.5 and MODIS) with in-situ data of 19 study areas from Oleksyn et al. (2000). They measured the NPP from Pinus sylvestris in 19 study areas. We selected the predicted and from satellite obtained NPP values for each study site. Since a grid cell of CLM4.5 can have several PFTs and P. silvestris is a needleleaf tree and distributes in temperate and boreal zones, we selected the percentage of two PFTs (i.e. Needleleaf Evergreen Temperate and Boreal Forests) for each grid cell, where the in-situ studies were done, and multiplied with the total NPP value of each $25 \times 25 \mathrm{~km}$ grid cell. In the Table 4, the study sites, the NPP values from the sources of Oleksyn et al. (2000), CLM4.5 and MODIS 4x4 km resolution and the total percentage of the two PFTs are presented. Comparing of the NPP values of in-situ studies with the results of CLM4.5 and MODIS shows that the CLM4.5 has a better correlation with the NPP from Oleksyn et al. (2000) than MODIS (see Table 4 col. 2, 5 and 6). The scatter plot in Fig. 5 presents the correlation between in-situ and CLM4.5 and MODIS with correlation coefficient $R^{2}$. The correlation of NPP between CLM4.5 and in-situ studies equates to $63 \%$ and between MODIS and in-situ studies ca. 1\%, respectively (see Fig. 5). Certainly, it has to be mentioned that the correlation analysis includes in-situ data from one plant species in different study areas and climate zones. 
Table 4. In-situ NPP data from 19 study sites that collected from Oleksyn et al. (2000), predicted NPP for $25 \times 25 \mathrm{~km}$ grid resolution and PFT's percentage of each grid according to the PFT in the study sites, and the observed NPP by MODIS.

\begin{tabular}{|c|c|c|c|c|c|}
\hline & \multicolumn{5}{|c|}{$\mathrm{NPP}\left(\mathrm{gC} \cdot \mathrm{m}^{-2} \cdot \mathrm{yr}^{-1}\right)$} \\
\hline Lat, Lon & $\begin{array}{l}\text { Oleksyn et } \\
\text { al. (2000) }\end{array}$ & $\begin{array}{c}\text { CLM4.5 } \\
25 \times 25 \mathrm{~km}\end{array}$ & PFT (\%) & $\begin{array}{c}\text { CLM } 4.5 x \\
\text { PFT }\end{array}$ & $\begin{array}{l}\text { MODIS } \\
4 \times 4 \mathrm{~km}\end{array}$ \\
\hline $53.60,20.00$ & 820 & 1222 & 0.65 & 794.3 & 642 \\
\hline $53.20,23.37$ & 740 & 1172 & 0.91 & 1066.52 & 608 \\
\hline $53.00,13.90$ & 1070 & 1062 & 0.43 & 456.66 & 711 \\
\hline $52.50,10.50$ & 690 & 945 & 0.56 & 529.2 & 633 \\
\hline $51.60,20.20$ & 870 & 1519 & 0.46 & 698.74 & 507 \\
\hline $51.10,17.92$ & 980 & 1288 & 0.83 & 1069.04 & 530 \\
\hline $50.80,4.43$ & 900 & 1302 & 0.78 & 1015.56 & 611 \\
\hline $49.5,8.5$ & 930 & 727 & 0.92 & 668.84 & 344 \\
\hline $48.8,7.78$ & 580 & 877 & 0.69 & 605.13 & 804 \\
\hline $48.77,17.05$ & 470 & 1333 & 0.34 & 453.22 & 306 \\
\hline $47.30,16.47$ & 940 & 1207 & 0.88 & 1062.16 & 701 \\
\hline $44.1,17.35$ & 220 & 1300 & 0.19 & 247 & 746 \\
\hline $43.2,19.5$ & 100 & 1456 & 0.16 & 232.96 & 672 \\
\hline $40.0,31.17$ & 80 & 854 & 0.08 & 68.32 & 439 \\
\hline $60.25,29.9$ & 260 & 766 & 0.51 & 390.66 & 413 \\
\hline $60.18,15.87$ & 180 & 626 & 0.29 & 181.54 & 572 \\
\hline $59.97,33.50$ & 350 & 928 & 0.61 & 566.08 & 490 \\
\hline $58.83,29.12$ & 410 & 942 & 0.56 & 527.52 & 477 \\
\hline $55.75,26.67$ & 700 & 1165 & 0.67 & 780.55 & 427 \\
\hline
\end{tabular}

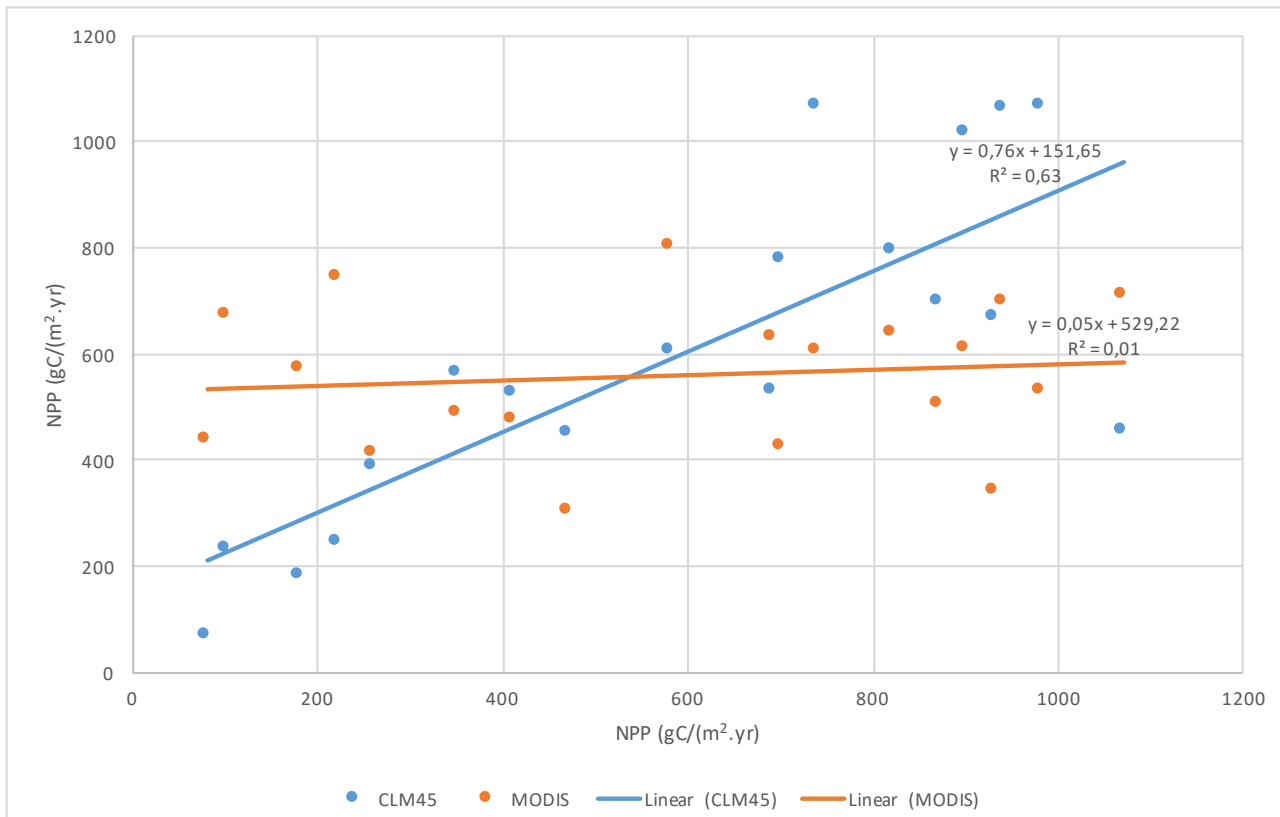

Figure 5. Scatter plot for the correlation analysis between in-situ collected NPP data from Oleksyn et al. (2000) and by CLM4.5 predicted, and by MODIS observed data. The lines show the linear correlarion. 
This study shows that CLM4.5 model predicts NPP fairly good for $25 \times 25 \mathrm{~km}$ spatial resolution in pan-European scale. In 30 Nov. 2015, United Nations came together in Paris (France) (United Nations Framework Convention on Climate Change, 21st Conference of the Parties (COP 21)) to discuss the effect of $2{ }^{\circ} \mathrm{C}$ average global temperature increase on ecosystems, economies, human health and adjust preferences for a road map for reducing anthropogenic factors, which caused the temperature increase globally. In last decade, the meaning of $2{ }^{\circ} \mathrm{C}$ global average temperature has been increased and its effects on terrestrial biosphere, especially on carbon assimilation processes, has become increasingly important for all nations. The future climate predictions show that the $2{ }^{\circ} \mathrm{C}$ average temperature increase in pan-European scale under consideration the Representative Concentration Pathways 4.5 (RCP4.5) emission scenario earliest in 2033 and latest 2065 (Kirtman et al., 2013). The RCP4.5 is consistent with a possible change in future anthropogenic greenhouse gases emissions (GHG). The RCP4.5 is named after the potential change of radiative forcing value +4.5 $\frac{W}{m^{2}}$ in 2100 relative to 1860 (pre-industrial) value (Meinshausen et al., 2011). The GHG

emissions within the RCP4.5 scenario peaks close to 2040, and then stats to decline up to 2100. We decided to predict the NPP for 30-year period between 2034 and 2063 to identify the climate change effect on net primary production of the vegetation in panEuropean scale. In the Fig. 6, we show the distribution of 30 years (2034-2063) average of NPP, the change between 2000-2014 and 2034-2063 and also the trend of NPP change up to 2100 in pan-European scale.
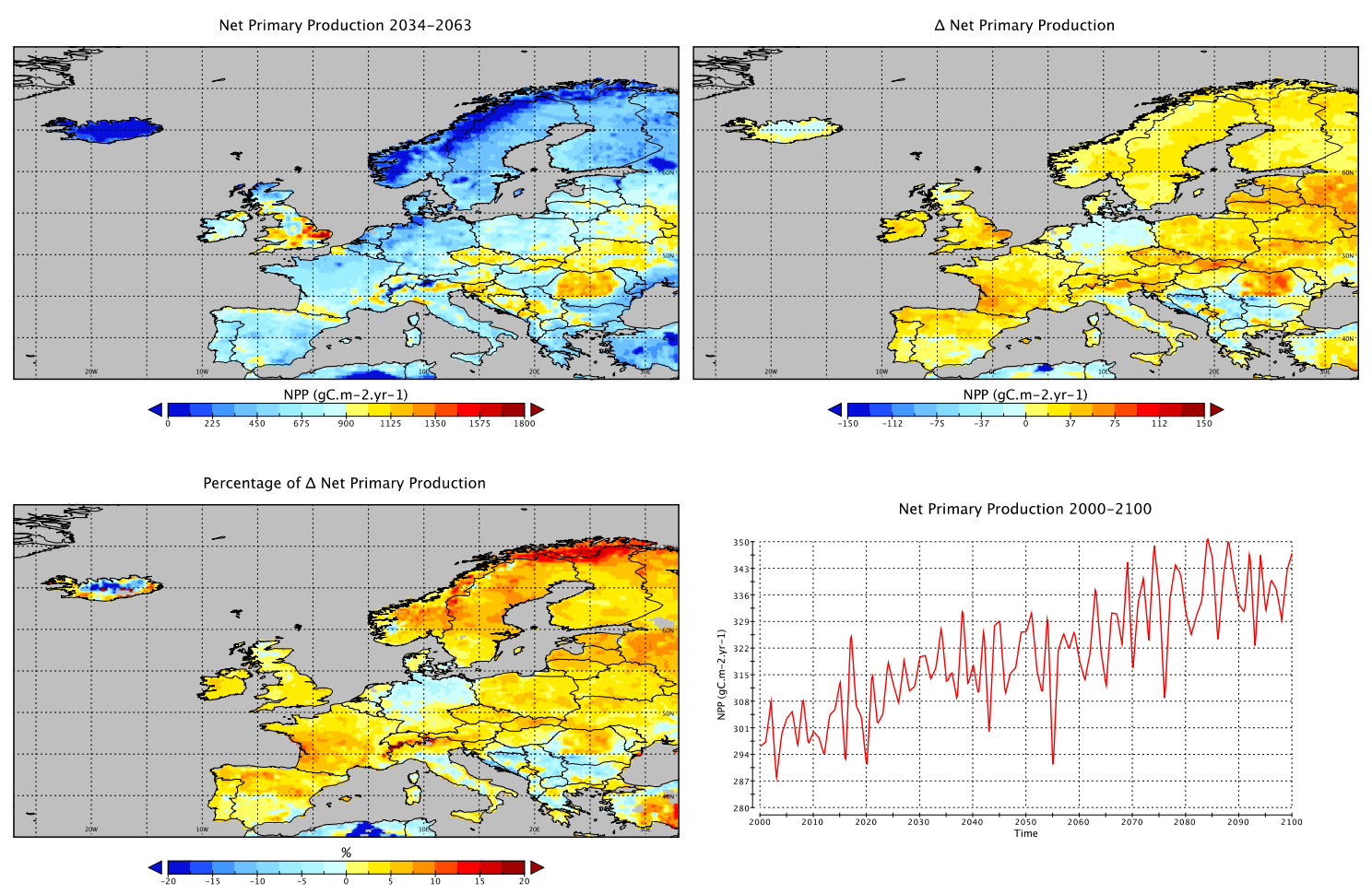

Figure 6. By CLM4.5 predicted NPP for the future period (2034-2063) (upper left), the difference between 30 years (1971-2000) average of past period and future period (2034-2063) (upper right), the percentage of the difference between two periods (bottom left), and the NPP of the run of the model from 1971 to 2100 (bottom right). 
Generally, NPP shows an increasing up to $30 \%$ in pan-European scale during the peak period of GHG emissions (2034-2063) (see Figs. 6 upper right and bottom left). However, the future prediction of NPP shows a decreasing in most of the regions in Germany, Italy and south-east Europe. The model illustrates up to $18 \%$ of reduction by NPP in that regions (see Fig. 6 bottom left). It is quite important to investigate not only spatial distribution of NPP but also inter-annual variability of NPP. The sub Fig. 6 (bottom right) shows the trend of average NPP variability from 1971 to 2100 . NPP has a distinct increasing trend between 1971-2100. From 1971 to 2100 there is almost $15 \%$ an increase in NPP (see Fig. 6 bottom right).

\section{Conclusion}

This study compares predicted NPP by using CLM4.5 model with remotely sensed NPP in pan-European scale with in-situ measured data. The comparison was done for $25 \times 25 \mathrm{~km}$ high resolution gridded data sets. It reveals that there are differences between modelled and observed NPP in eastern and middle Europe. NPP is either mis-quantified by MODIS or mis-predicted by CLM4.5. Since we do not have field studies in the regions, we could not detect the site of the failure in this study. But the high correlation between by CLM4.5 predicted and observed data in 19 study locations indicates that the model is most probably able to predict NPP in pan-European scale. According to the results in past observed period, we assume that the prediction of NPP quite acceptable for the future period. It shows that NPP will increase ca. $15 \%$ in average at panEuropean level. Furthermore, northern and high altitude regions show most response to climate change with highest increase of NPP in the future period. Although NPP shows an increasing trend in most of the vegetated areas at pan-European level, NPP will minimally change in few regions e.g. in Germany, Italy and most of the Balkans.

Acknowledgments. The research has received funding from the European Community Seventh Framework Program (FP7/2007-2013) under grant agreement Nr. 282746 (IMPACT2C).

\section{REFERENCES}

[1] Bonan, G.B. (2008): Forests and climate change: forcings, feedbacks, and the climate benefits of forests. - Science 320: 1444-1449.

[2] Cao, M., Woodward, F.I. (1998): Net primary and ecosystem production and carbon stocks of terrestrial ecosystems and their responses to climate change. - Global Change Biology 4: 185-198.

[3] Chapin, F.S., Matson, P.A., Vitousek, P.M. (2011): Principles of Terrestrial Ecosystem Ecology, $2^{\text {nd }}$ Edition, pp. 179. Springer New York, Dordrecht, Heidelberg, London. Doi: 10.1007/978-1-4419-9504-9

[4] Guillem, C., Allen, J.I., Bopp, L., Schrum, C., Holt, J., Tsiaras, K., Zavatarelli, M., Chifflet, M., Cannaby, H., Dadou, I., Daewel, U., Wakelin, S. L., Machu, E., Pushpadas, D., Butenschon, M., Artioli, Y., Petihakis, G., Smith, C., Garçon, V., Goubanova, K., Le Vu, B., Fach, B. A., Salihoglu, B., Clementi, E., Irigoien, X. Biomass changes and trophic amplification of plankton in a warmer ocean. - Global Change Biology 20(7): 2124-2139.

[5] Del Grosso, S., Parton, W., Stohlgren, T., Zheng, D., Bachelet, D., Prince, S., Hibbard, K., Olson, R. (2008): Global potential net primary production predicted from vegetation class, precipitation, and temperature: Erratum. - Ecology 89(8): 2117-2126. 
[6] Dixon, R.K., Solomon, A.M., Brown, S., Houghton, R.A., Trexier, M.C., Wisniewski, J. (1994): Carbon pools and flux of global forest ecosystem. - Science 263: 185-190. Doi: 10.1126/science.263.5144.185

[7] Donmez, C., Berberoglu, S., Curran, P.J. (2011): Modelling the current and future distribution of NPP in a Mediterranean watershed. - International Journal of Applied Earth Observation and Geoinformation 13(3): 336-345. Doi: 10.1016/j.jag.2010.12.005

[8] Easterling, W.E., Aggarwal, P.K., Batima, P., Brander, K.M., Erda, L., Howden, S.M., Kirilenko, A., Morton, J., Soussana, J.F., Schmidhuber J., Tubiello, F.N. (2007): Food, fibre and forest products. - In: Parry, M.L., Canziani, O.F., Palutikof, J.P., van der Linden, P.J., Hanson, C.E. (Eds.) Climate Change 2007: Impacts, Adaptation and Vulnerability. Contribution of Working Group II to the Fourth Assessment Report of the Intergovernmental Panel on Climate Change, Cambridge University Press, Cambridge, UK, 273-313.

[9] Esser, G. (1998): NPP Multi-Biome: Global Osnabruck Data, 1937-1981. Data set. Available on-line [http://daac.ornl.gov] from Oak Ridge National Laboratory Distributed Active Archive Center, Oak Ridge, Tennessee, U.S.A. doi:10.3334/ORNLDAAC/214

[10] Esser, G., Kattge, J., Sakalli, A. (2012): Feedback of carbon and nitrogen cycles enhances carbon sequestration in the terrestrial biosphere. - Global Change Biology 17(2): 819842. doi:10.1111/j.1365-2486.2010.02261.x.

[11] Huston, M.A., Wolverton, S. (2009): The global distribution of net primary production: resolving the paradox. - Ecological Monographs 79(3): 343-377. Doi: 10.1890/08-0588.1

[12] Kauppi, P.E., Mielikainen, K., Kuusela, K. (1992): Biomass and carbon budget of European forests, 1971-1990. - Science 256(5053): 70-4.

[13] Kirschbaum, M.U.F. (2000): Forest growth and species distribution in a changing climate. - Tree Physiology 20: 309-322

[14] Kirtman, B., Power, S.B., Adedoyin, J.A., Boer, G.J., Bojariu, R., Camilloni, I., DoblasReyes, F.J., Fiore, A.M., Kimoto, M., Meehl, G.A., Prather, M., Sarr, A., Schär, C., Sutton, R., van Oldenborgh, G.J., Vecchi G., Wang, H.J. (2013): Near-term Climate Change: Projections and Predictability. - In: Stocker, T.F., D. Qin, G.-K. Plattner, M. Tignor, S.K. Allen, J. Boschung, A. Nauels, Y. Xia, V. Bex and P.M. Midgley (eds.) Climate Change 2013: The Physical Science Basis. Contribution of Working Group I to the Fifth Assessment Report of the Intergovernmental Panel on Climate Change. Cambridge University Press, Cambridge, United Kingdom and New York, NY, USA

[15] Koven, C.D., Riley, W.J., Subin, Z.M., Tang, J.Y., Torn, M.S., Collins, W.D., Bonan, G.B., Lawrance, D.M., Swenson, S.C. (2013): The effect of vertically resolved soil biogeochemistry and alternate soil $\mathrm{C}$ and $\mathrm{N}$ models on $\mathrm{C}$ dynamics of CLM4. Biogeosciences 10: 7109-7131. Doi: 10.5194/bg-10-7109-2013

[16] Lawrence, P.J., Chase, T.N. (2007): Representing a MODIS consistent land surface in the Community Land Model (CLM 3.0). - Journal of Geophysical Research 112(G01023): 117. Doi: $10.1029 / 2006 J G 000168$

[17] Lieth, H. (1975): Primary production of the major vegetation units of the world. - In: (Lieth, H., Whittaker, R.H. (eds.) Primary Productivity of the Biosphere. Ecological Studies 14. Springer-Verlag, New York and Berlin. pp. 203-215.

[18] Liu, J., Chen, J.M., Cihlar, J., Park, W.M. (1997): A process based boreal ecosystem productivity simulator using remote sensing inputs. - Remote Sensing of Environment 62(2): 158-175. Doi: 10.1016/S0034-4257(97)00089-8

[19] Maselli, F., Marii, R., Chiesi, M. (2013): Use of lidar data to simulate forest net primary production. - International Journal of Remote Sensing 34(7): 2487-2501. Doi: 10.1080/01431161.2012.745019

[20] Meinshausen, M., Smith, S.J., Calvin, K., Daniel, J.S., Kaunuma, M.L.T., Lamarque, JF., Matsumoto K. et al. (2011): The RCP greenhouse gas concentrations and their extensions from 1765 to 2300. - Climatic Change 109: 213-241. DOI: 10.1007/s10584011-0156-z 
[21] Melillo, J.M., McGuire, A.D., Kicklighter, D.W., III Moore, B., Vorosmarty, C.J., Schloss, A.L. (1993): Global climate change and terrestrial net primary production. Nature 363: 234-240.

[22] Oleksyn, J., Reich, P.B., Rachwal, L., Tjoelker, M.G. (2000): Variation in aboveground net primary production of diverse European Pinus sylvestris populations. - Trees Structure and Function 14(7): 415-421.

[23] Olson, D.M., Dinerstein, E., Wikramanayake, D.E., Burgess, N.D., Powell, G.V.N., Underwood, E.C., D'Amico, J.A. et al. (2001): Terrestrial Ecoregions of the World: A New Map of Life on Earth. - BioScience 51(11): 933-938.

[24] Pachavo, G., Murwira, A. (2014): Remote sensing net primary productivity (NPP) estimation with the aid of GIS modelled shortwave radiation (SWR) in a Southern African Savanna. - International Journal of Applied Earth Observation and Geoinformation 30: 217-226. Doi: 10.1016/j.jag.2014.02.007

[25] Pan Y., Birdsay, R., Hom, J., McCullough, K., Clark, K. (2006): Improved estimates of net primary productivity from MODIS satellite data at regional and local scales. Ecological Applications 16(1): 125-132. Doi: 10.1890/05-0247

[26] Prieto-Blanco A, North, P.R.J, Barnsley, M.J, Fox, N. (2009): Satellite-driven modelling of Net Primary Production (NPP): Theoretical analysis. - Remote Sensing of Environment 113: 137-147. Doi: 10.1016/j.rse.2008.09.002

[27] Running, S., Mu, Q., Zhao, M. (2015): MOD17A3H MODIS/Terra Net Primary Production Yearly L4 Global 500m SIN Grid V006. NASA EOSDIS Land Processes DAAC. http://doi.org/10.5067/MODIS/MOD17A3H.006

[28] Schmithüsen, J. (1976): Atlas zur Biogeographie. Meyer, Mannheim, Germany. ISBN: 3411-00303-0

[29] Schulzweida, U. (2015): Climate Data Operators (CDO) version 1.7 User's Guide. Available at https://code.zmaw.de/projects/cdo/embedded/cdo.pdf

[30] Thomey, M.L., Collins, S.L., Vargas, R., Johnson, J.E., Brown, R.F., Natwig, D.O., Friggens, M.T. (2011): Effect of precipitation variability on net primary production and soil respiration in a Chihuahuan desert grassland. - Global Change Biology 17: 15051515. Doi: 10.1111/j.1365-2486.2010.02363.x

[31] Turner, D.P., Ollinger, S., Smith, M.-I., Krankina, O., Gregory, M. (2004): Scaling net primary production to a MODIS footprint in support of Earth observing system product validation. - International Journal of Remote Sensing 25(10): 1961-1979. Doi: 10.1080/0143116031000150013

[32] Turner, D.P., Ritts, W.D., Cohen, W.B., Gower, S.T., Running, S.W., Zhao, M., Costa, M.H., Kirschbaum, A.A., Ham, J.M., Saleska, S.R., Ahl, D.E. (2006): Evaluation of MODIS NPP and GPP products across multiple biomes. - Remote Sensing of Environment 102(3-4): 282-292. Doi: 10.1016/j.rse.2006.02.017

[33] Ummenhofer, C.C., Xu, H., Twine, T.E., Girvetz, E.H., McCarthy, H.R., Chhetri, N., Nicholas, K.A. (2015): How climate change affects extremes in maize and wheat yield in two cropping regions. - Journal of Climate 28: 4653-4687. Doi: 10.1175/JCLI-D-1300326.1

[34] Wan, S., Hui, D., Wallace, L., Luo, Y. (2005): Direct and indirect effects of experimental warming on ecosystem carbon processes in a tallgrass prairie. - Global Biogeochemical Cycles 19(GB2014): 1-13. Doi: 10.1029/2004GB002315

[35] Wang, C. (2016): A remote sensing perspective of alpine grasslands on the Tibetan Plateau: Better or worse under "Tibet Warming"?. - Remote Sensing Applications: Society and Environment 3: 36-44. Doi: 10.1016/j.rsase.2015.12.002

[36] Zhao, M., Heinsch, F.A., Nemani, R.R., Running, S.W. (2005): Improvements of the MODIS terrestrial gross and net primary production global data set. - Remote Sensing of Environment 95(2): 164-176. Doi: 10.1016/j.rse.2004.12.011 
[37] Zhao, M., Running, S.W., Nemani, R.R. (2006). Sensitivity of Moderate Resolution Imaging Spectroradiometer (MODIS) terrestrial primary production to the accuracy of meteorological reanalyses. - Journal of Geophysical Research 111(G01002): 1-13.

[38] Zhao, M., Running, S.W. (2010): Drought-Induced reduction in global terrestrial net primary production from 2000 through 2009. - Science 329 (5994): 940-943. Doi: $10.1126 /$ science. 1192666 